\title{
PARTISIPASI PEREMPUAN TANI PADA KEGIATAN USAHATANI DAN PENYULUHAN TANAMAN PANGAN DI KECAMATAN SAKRA BARAT KABUPATEN LOMBOK TIMUR
}

\section{PARTICIPATION OF WOMEN WOMEN IN BUSINESS ACTIVITIES AND EXTENSION OF FOOD PLANTS IN SAKRA BARAT DISTRICT, EAST LOMBOK DISTRICT}

\author{
Baiq Lina Andriyani, Muktasam, Hayati \\ Program Studi Agribisnis Universitas Mataram \\ E-mail: baiq.linaandriyani@gmail.com
}

\begin{abstract}
ABSTRAK
Partisipasi Perempuan tani pada kegiatan usahatani dan penyuluhan tanaman pangan di Kecamatan Sakra Barat, Kabupaten Lombok Timur ditujukan untuk mengetahui partisipasi perempuan tani dalam kegiatan usahatani tanaman pangan, mengetahui partisipasi perempuan tani penyuluhan, menhetahui kendala-kendala yang dihadapi perempuan tani dalam kegiatan penyuluhan. Jumlah responden penelitian sebanyak 45 orang yang ditentukan secara random. Data primer dikumpulkan melalui wawancara yang menggunakan kuisioner. Tahapan analisis data terdiri dari uji hipotesis. Hasil penelitian menunjukkan bahwa tingkat partisipasi perempuan tani dalam kegiatan usahatani tanaman pangan tinggi sebanyak $71 \%$, tingkat partisipasi perempuan tani dalam penyuluhan tanaman pangan rendah sebanyak $91 \%$, kendala-kendala yang mempengruhi rendahnya partisipasi responden dalam kegiatan penyuluhan yaitu jarak yang jauh, waktu yang kurang tepat dan tempat yang kurang nyaman, tidak bisa membaca dan menulis.
\end{abstract}

Kata kunci: Partisipasi, Usahatani, Penyuluhan, Tanaman Pangan

\section{ABSTRACT}

The participation of farm women in farming activities and extension of food crops in Sakra Barat District, East Lombok Regency is aimed at knowing the participation of farm women in food crop farming activities, knowing the participation of extension farm women, knowing the constraints faced by farm women in extension activities. The number of research respondents were 45 people who were randomly assigned. Primary data were collected through interviews using questionnaires. Stages of data analysis consists of hypothesis testing. The results showed that the level of participation of women farmers in farming activities of food crops was as high as 71\%, the level of participation of women farmers in extension of food crops was as low as $91 \%$, the constraints that affected the low participation of respondents in extension activities namely long distances, less time right and less comfortable place, can't read and write.

Keywords: Participation, Farming, Extension, Food Crops 


\section{PENDAHULUAN}

Pertanian masih menjadi sektor penting dalam pembangunan ekonomi di indonesia. Peran penting sektor pertanian tersebut menjadikan pembangunan pertanian sebagai prioritas dalam setiap langkah pembangunan. Sektor tanaman pangan adalah sektor yang strategis dalam pembangunan pertanian karena terkait dengan kebutuhan hidup penduduk Indonesia yang terus bertambah. Salah satu kebijakan pada Rencana Strategis Kementerian Pertanian 2015-2019 adalah peningkatan swasembada beras dan peningkatan produksi jagung dan kedelai. Beras dan kedelai juga ditetapkan menjadi barang kebutuhan pokok, sedangkan benih padi, jagung, dan kedelai ditetapkan menjadi barang penting berdasarkan Peraturan Presiden Republik Indonesia Nomor 71 Tahun 2015 (Kementerian Pertanian, 2015).

Partisipasi perempuan dalam pembangunan pertanian mutlak sangat diperlukan karena sebagai modal dasar pembangunan. Untuk mensejahterakan tenaga kerja perempuan dalam konsep-konsep kerja bukan sematamata masalah mengejar kepentingan, dari segi ekonomis atau peningkatan pendapatan, akan tetapi bertujuan untuk meningkatkan partisipasi atau peranan perempuan dalam masyarakat. Untuk pengelolaan usahataninya, tidak hanya laki-laki saja yang terlibat didalamnya tetapi perempuan juga ikut berperan. Partisipasi diartikan sebagai keterlibatan masyarakat secara aktif dalam setiap tahapan pembangunan mulai dari perencanaan, pelaksanaan, evaluasi, dan pemanfaatan hasil (Listiani, 2012).

Penyuluhan pertanian menjadi salah satu kegiatan penting dalam mendukung tercapainya tujuan program peningkatan produksi pangan. Oleh karena itu, setiap penyuluh pertanian harus mampu melaksanakan peran yaitu sebagai penganalisa yang selalu melakukan analisis tehadap alternatif pemecahan masalah atau kebutuhan, sebagai penasehat yaitu memiliki alternatif perubahan yang paling tepat, sebagai organisatir yaitu harus mampu menjalin hubungan baik dengan segenap lapisan masyarakat dan mampu menumbuhkan kesadaran serta menggerakan partisipasi masyarakat (Mardikanto, 2009).

Lombok Timur sebagai salah satu Kabupaten dari 10 Kabupaten kota di NTB juga melaksanakan program peningkatan produksi pangan. Kegiatan penyuluhan tanaman pangan di Kecamatan Sakra Barat didukung oleh keberadaan Balai Penyuluhan Pertanian (BPP) dan tenaga penyuluh yang profesional, dari 15 penyuluh Pertanian Lapangan (PPL) yang ada di Kecamatan Sakra Barat tersebar di 18 Desa yang menjadi wilayah kerja BPP Sakra Barat, ditetapkan 3 Desa yang menjadi tempat penelitian dilakukan yaitu Desa Sukarara, Mengkuru, dan Gunung Rajak.

Berdasarkan uraian diatas, maka masalah yang ditelaah sebagai pertanyaan penelitian adalah: 1) bagaimana partisipasi perempuan tani dalam kegiatan usahatani tanaman pangan; 2) bagaimana pastisipasi perempuan tani dalam kegiatan penyuluhan tanaman pangan; 3) Apa saja kendala - kendala yang dihadapi perempuan tani dalam kegiatan penyuluhan tanaman pangan.

Berdasarkan permasalahan, tujuan penelitian ini adalah: 1) untuk mengetahui partisipasi perempuan tani dalam kegiatan usahatani tanaman pangan; 2) untuk mengetahui partisipasi perempuan tani dalam kegiatan penyuluhan tanaman pangan; 3) untuk mengetahui kendala-kendala yang dihadapi perempuan tani dalam kegiatan penyuluhan tanaman pangan.

\section{METODE PENELITIAN}

Metode yang digunakan dalam penelitian ini adalah metode deskriptif yaitu suatu metode dalam meneliti status sekelompok manusia, suatu objek, suatu set kondisi, suatu sistem pemikiran ataupun suatu kelas peristiwa pada masa sekarang. Dengan tujuan untuk memberikan deskripsi, gambaran atau lukisan secara sistematis, faktual dan akurat mengenai fakta-fakta, sifat-sifat serta hubungan antara fenomena yang diselidiki (Nazir, 2005).

Unit analisis dalam penelitian ini adalah rumah tangga usahatani yaitu perempuan tani baik itu ibu maupun anak perempun yang ikut dalam kegiatan usahatani di Kecamatan Sakra Barat. Lokasi penelitian di kecamatan Sakra Barat dengan pemilihan daerah penelitian ditentukan secara sengaja atau purposive sampling yaitu pengambilan sampel daerah berdasarkan ciri atau sifat dengan pertimbangan tertentu. Daerah penelitian yang diambil dengan pertimbangan merupakan terdapatnya desa dengan kelompok tani yang aktif melakukan kegiatan usahatani maupun penyuluhan tanaman pangan di beberapa Desa yang ada di Kecamatan Sakra Barat tersebut. Hal tersebut diinformasikan langsung oleh petugas lapang yang bertugas di Kecamatan Sakra Barat tersebut. Dalam penelitian ini dipilih masing-masing desa di Kecamatan Sakra Barat untuk menjadi lokasi penelitian yaitu Desa Sukarara, Desa Mengkuru dan Desa Gunung Rajak.

Dalam penelitian ini yang menjadi responden adalah istri atau perempuan tani yang melakukan kegiatan usahatani. Penentuan jumlah responden dilakukan secara "Quota Sampling" yaitu ditetapkan sebanyak 45 responden, dimana masing-masing desa diambil satu kelompok tani dengan cara "purposive sampling" atas pertimbangan jumlah anggota terbanyak yang kemudian diambil masing-masing 15 responden, kemudian dalam penentuan 45 responden ditentukan secara "Random Sampling" yaitu teknik pengambilan sampel secara acak.

Data yang digunakan dalam penelitian ini adalah data kuantitatif dan data kualitatif. Data kuantitatif adalah data yang berupa angka yang didapat dari responden. Data kualitatif adalah data hasil wawancara 
langsung dengan petani responden dengan berpedoman pada pertanyaan atau kuesioner, data yang diperoleh adalah data berupa bukan angka.

Data primer adalah data yang diperoleh dari hasil wawancara langsung kepada responden dengan berpedoman pada daftar pertanyaan. Sedangkan data sekunder adalah data atau informasi yang sudah didokumentasikan, baik berupa data statistik maupun hasil penelitian yang diperoleh dari dinas atau instansi dan lembaga yang terkait dengan keperluan penelitian ini.

Untuk mengetahui tingkat partisipasi perempuan dalam kegiatan usahatani dan penyuluhan tanaman pangan diukur dengan sistem skor yang diperoleh dengan kriteria yang telah ditetapkan.

Skor maksimum $=\sum$ Item $x$ Skor Tertinggi

Skor minimum $=\sum$ Item $\mathrm{x}$ Skor Terendah

Interval skor $\quad=$ jumlah skor maksimal - jumlah skor minimal

Jumlah kategori

\section{HASIL DAN PEMBAHASAN}

\section{Partisipasi dalam Kegiatan Usahatani Tanaman Pangan}

Partisipasi perempuan tani pada kegiatan usahtani tanaman pangan adalah partisipasi perempuan pada tahap perencanaan, pelaksanaan, evaluasi dan pemanfaatan hasil atas partisipasinya dalam melakukan kegiatan usatahani tanaman pangan. berdasarkan empat tahapan tersebut tergolong "tinggi". Hasil penelitian ini juga sesuai dengan kajian empirik dari Hayati (2013) mengatakan bahwa partisipasi perempuan tani dalam kegiatan pertanian adalah dalam kategori tinggi, yang dilihat pada komponen perencanaan, pelaksanaan, evaluasi dan manfaat.

Hasil penelitian menunujukkan bahwa, partisipasi responden dalam kegiatan usahatani tanaman pangan adalah tinggi dengan total skor 53. Untuk lebih jelasnya dapat dilihat pada tabel 1 berikut.

Tabel 1. Partisipasi dalam Kegiatan Usahatani Tanaman Pangan

\begin{tabular}{llll}
\hline No & Variabel & Modus & Ketegori \\
\hline 1 & Perencanaan & 12 & Tinggi \\
2 & Pelaksanaan & 31 & Sedang \\
3 & Evaluasi & 6 & Tinggi \\
4 & Pemanfaatan Hasil & 4 & Sedang \\
\hline Total skor & & 53 & Tinggi \\
\hline
\end{tabular}

Sumber: Data Primer diolah Tahun 2019

\section{Partisipasi pada Tahapan Perencanaan}

Secara keseluruhan, partisipasi perempuan tani pada tahap perencanaan tergolong tinggi. Hal ini juga didukung oleh hasil penelitian Mulyaningsih, et al. (2018) yang menyatakan bahwa dalam tahapan ini juga tergolong dalam kategori tinggi dan dapat dilihat dari keikutsertaan perempuan tani mulai dari merumuskan jenis kegiatan, sarana produksi, tenaga kerja dan biaya, dan dalam menentukan waktu.

Hasil penelitian menunjukkan bahwa partisipasi responden dalam tahapan perencanaan adalah tinggi dengan total skor sebanyak 12. Untuk lebih jelasnya dapat dilihat pada tabel 2 berikut.

Tabel 2. Partisipasi responden pada Tahapan Perencanaan

\begin{tabular}{llll}
\hline No & Variabel & Modus & Kategori \\
\hline 1 & Merumuskan Jenis Kegiatan & 3 & Tinggi \\
2 & Merumuskan Sarana Produksi & 3 & Tinggi \\
3 & Merumuskan TK dan Biaya & 3 & Tinggi \\
4 & Menentukan Waktu & 3 & Tinggi \\
\hline Total Skor & & 12 & Tinggi \\
\hline
\end{tabular}

Sumber: Data Primer diolah Tahun 2019

Data pada tabel 2, menunjukkan bahwa akses responden terhadap sarana produksi pertanian berada dalam kategori tinggi, yang memberikan arti bahwa responden memiliki akses yang cukup optimal terhadap sarana produksi pertanian.

Kegiatan usahatani memerlukan tenaga kerja, baik tenaga kerja pria maupun tenaga kerja wanita yang berasal dari luar keluarga dan dari dalam keluarga. Perempuan tani lebih banyak mencurahkan tenaganya dibandingkan dengan tenaga kerja pria. Partisipasi responden juga sangat tinggi dalam menentukan biaya yang dibutuhkan selama proses kegiatan usahatani tanaman pangan mulai dari pembelian benih sampai panen, karena akses perempuan tani relatif tinggi terhadap pasar, terutama berkaitan dengan penyediaan kebutuhan selama proses kegiatan usahatani. 
Curahan waktu adalah alokasi waktu yang digunakan responden dalam melakukan usahatani tanaman pangan setiap musim tanam. Responden melakukan usahatani tanaman pangan setiap musim tanam datang. Aktivitas pengelolaan usahatani tanaman pangan dilakukan pada musim hujan di akhir bulan november sampai dengan bulan desember, adapun pada musim kemarau di awal bulan april sampai bulan mei.

\section{Partisipasi pada Tahapan Pelaksanaan}

Pada tahapan pelaksanaan secara umum partisipasi responden adalah tinggi. Hal ini juga didukung oleh hasil penelitian Mulyaningsih el al (2018) yang menyatakan bahwa terdapat persamaan partisipasi antara lakilaki dan perempuan dalam perencanaan dan pelaksanaan,dimana petani laki-laki dan perempuan berada pada kategori tinggi.

Hasil penelitian menunjukkan bahwa partisipasi responden dalam tahapan pelaksanaan pada kegiatan usahatani tanaman pangan adalah sedang, dimana jumlah skornya 31. Untuk lebih jelasnya dapat dilihat pada tabel 3 berikut.

Tabel 3. Partisipasi pada Tahapan Pelaksanaan

\begin{tabular}{llll}
\hline No & Variabel & Modus & Kategori \\
\hline 1 & Pengolahan Tanah & 3 & Sedang \\
2 & Pembibitan & 3 & Tinggi \\
3 & Penanaman & 3 & Tinggi \\
4 & Penyiangan & 5 & Tinggi \\
5 & Pengendalian Hama \& Penyakit & 6 & Tinggi \\
6 & Pemupukan & 4 & Sedang \\
7 & Pengairan & 4 & Rendah \\
8 & Panen \& pasca panen & 3 & Tinggi \\
\hline Total Skor & & 31 & Sedang \\
\hline
\end{tabular}

Sumber: Data Primer diolah Tahun 2019

Data pada tabel 3, menunjukkan bahwa pada kegiatan pengolahan tanah termasuk dalam kategori sedang. Mengingat kegiatan ini disamping membutuhkan tenaga dan fisik juga membutuhkan perhatian dan kesetaraan serta keteraturan, saat pengolahan lahan responden tidak terlibat langsung dilapangan karena pengolahan lahan termasuk pekerjaan yang berat dan biasanya menggunakan traktor dan dilakukan olek laki-laki. Keterlibatan responden hanya pada penentuan cara pengolahan dan waktu pengolahan karena responden berperan dalam menyediakan makanan untuk para pekerja.

Kegiatan pembibitan termasuk dalam kategori tinggi. Pada kegiatan pembibitan responden lebih banyak terlibat karena kegiatan ini tidak terlalu berat dan memerlukan ketelatenan. Peran responden dalam pembibitan yang dimaksud dalam penelitian ini adalah keterlibatan responden dalam kegiatan persemaian benih padi meliputi pemilihan benih yang akan digunakan, perendaman dan penaburan benih ke lahan persemaian. Berdasarkan tabel 4.16, dapat diketahui bahwa rata-rata responden ikut berperan dalam persemaian padi sawah. Tingginya persentase rata-rata peranan perempuan tani menunjukkan bahwa responden sangat berperan dalam kegiatan pembibitan.

kegiatan penanaman termasuk dalam kategori tinggi. Hal ini tunjukkan dalam kegiatan penanaman didahului dengan pencabutan bibit dari tempat persemaian kemudian ditanam pada lahan yang sudah disediakan. Peranan responden dalam kegiatan penanaman padi akan dilihat dari keikutsertaan responden dalam kegiatan penanaman.

Kegiatan penyiangan termasuk dalam kategori tinggi. Hal ini tunjukkan dengan keterlibatan responden dalam menentukan waktu penyiangan, mencari tenaga kerja, biaya yang akan dikeluarkan, penyedian makanan sampai mengantar makanan kepada para pekerja bahkan ada sebagian responden ikut membanrtu melakukan penyiangan sebelum pulang kerumah alasannya agar kegiatan penyiangan cepat selesai sehingga biaya yang dikeluarkan bisa berkurang.

Kegiatan pengendalian hama dan penyakit termasuk dalam kategori tinggi. Hal ini tunjukkan dengan keterlibatan responden mulai dari menentukan waktu, pembelian pestisida, untuk kegiatan pengendalian hama dan penyakit biasanya dilakukan oleh laki-laki karena pekerjaan ini membutuhkan tenaga yang kuat untuk mengangkat alat penyemprot hama dan penyakit tersebut.

Kegiatan pemupukan termasuk dalam kategori tinggi. Hal ini tunjukkan dengan keterlibatan responden mulai dari menentukan waktu, pembelian pupuk, untuk kegiatan pemupukan biasanya dilakukan oleh kaum pria, tetapi apabila kaum pria mempunyai pekerjaan lain biasanya kegiatan ini dilakukan oleh wanita tani dengan dibantu oleh anak dan keluarga atau menyuruh tenaga kerja dari luar keluarga.

Kegiatan pengairan termasuk dalam kategori rendah. Keterlibatan responden hanya pada penentuan waktu pengairan, mengantar makanan, Mengingat kegiatan ini disamping membutuhkan tenaga dan fisik juga membutuhkan perhatian dan kesetaraan serta keteraturan. 
Kegiatan panen dan pasca panen termasuk dalam kategori tinggi. Hal ini karena dalam kegiatan panen dan pasca panen padi responden juga berperan mulai dari menentukan waktu, mencari tenaga kerja beserta biaya yang dikeluarkan, penyedian makanan sampai mengantar makanan bahkan sebagian responden ikut terlibat dalam proses pengaritan, perontontokan dan penjemuran.

\section{Partisipasi pada Tahap Evaluasi}

Pada tahapan evaluasi secara umum partisipasi responden adalah tinggi. Hal ini juga didukung oleh hasil penelitian Hayati (2015) yang menyatakan bahwa skor partisipasi perempuan tani pada dimensi tahapan evaluasi adalah tinggi. Perempuan tani melakukan pengawasan pada kegiatan pertanian meskipun ia tidak melakukan pekerjan itu.

Hasil penelitian menunjukkan bahwa partisipasi responden dalam tahapan evaluasi pada kegiatan usahatani tanaman pangan adalah tinggi, dimana jumlah skornya 6. Untuk lebih jelasnya dapat dilihat pada tabel 4 berikut.

Tabel 4. Partisipasi pada Tahapan Evaluasi

\begin{tabular}{llll}
\hline No & Variabel & Total Skor & Kategori \\
\hline 1 & Proses Pengawasan Kegiatan Usahatani Tanaman Pangan & 3 & Tinggi \\
2 & Mengawasi Hasil Usahatani Tanaman Pangan & 3 & Tinggi \\
\hline Partisipasi Perempuan Tani & 6 & Tinggi \\
\hline
\end{tabular}

Sumber: Data Primer diolah Tahun 2019

Data pada tabel 4, menunjukkan bahwa pada kegiatan proses pengawasan kegiatan usahatani tanaman pangan termasuk dalam kategori tinggi. Hal ini tunjukkan dengan keterlibatan responden dalam mengawasi dan menilai jalannya setiap tahapan dalam kegiatan usahatani tanaman pangan.

Kegiatan mengawasi hasil usahatani tanaman pangan termasuk dalam kategori tinggi. Hal ini tunjukkan dengan keterlibatan responden dalam mengawasi hasil panen tetapi keterlibatannya juga dibarengi oleh keterlibatan laki-laki atau suami. Responden juga terlibat dalam memutuskan apakah hasil produksi pangan di sawah disimpan atau dijual, dan mengontrol penggunaan hasil panen dan penjualannya.

\section{Partisipasi pada Pemanfaatan Hasil}

Pada tahapan pemanfaatan hasil secara umum partisipasi responden adalah sedang. Hal ini juga didukung oleh hasil penelitian Mulyaningsih, el al. (2018) yang menyatakan bahwa meskipun perempuan memiliki partisipasi yang tinggi dalam kegiatan usahatani namun hanya sedikit yang merasakan manfaat untuk dirinya sendiri.

Hasil penelitian menunjukkan bahwa partisipasi responden dalam tahapan pemanfaatan hasil pada kegiatan usahatani tanaman pangan adalah sedang, dimana jumlah skornya 4. Untuk lebih jelasnya apat dilihat pada tabel 5 berikut.

Tabel 5. Partisipasi pada Tahapan Pemanfaatan Hasil

\begin{tabular}{llll}
\hline No & Variabel & Modus & Kategori \\
\hline 1 & Menggunakan alat-alat pertanian & 1 & Rendah \\
2 & Memanfaatkan hasil usahatani tanaman pangan & 3 & Sedang \\
\hline Total skor & 4 & Sedang \\
\hline
\end{tabular}

Sumber: Data Primer diolah Tahun 2019

Data pada tabel 5, menunjukkan bahwa pada keterlibatan dalam termasuk dalam menggunakan alat-alat pertananian kategori rendah. Hal ini tunjukkan dengan kurang terlibatnya responden dalam menggunakan alatalat usahatani, tetapi ada beberapa alat yang bisa digunakan juga oleh perempuan tani seperti sabit.

Pemanfaatan hasil usahatani tanaman pangan termasuk dalam kategori tinggi. Hal ini tunjukkan dengan keterlibatan responden dalam mengambil keputusan. Dalam pengambilan keputusan ini biasanya dilakukan bersama suami tetapi keterlibatan responden lebih dominan karena responden lebih mengerti kondisi kebutuhan rumah tangganya selain itu karena akses perempuan tani relatif tinggi terhadap pasar.

\section{Partisipasi dalam Kegiatan Penyuluhan Tanaman Pangan}

Hasil penelitian juga menunujukkan bahwa, partisipasi responden dalam kegiatan penyuluhan tanaman pangan adalah rendah dengan total skor 10. Untuk lebih jelasnya dapat dilihat pada tabel 6 berikut. 
Tabel 6. Partisipasi dalam Kegiatan Penyuluhan Tanaman Pangan

\begin{tabular}{llll}
\hline No & Variabel & Modus & Ketegori \\
\hline 1 & Perencanaan & 3 & Rendah \\
2 & Pelaksanaan & 6 & Sedang \\
3 & Evaluasi & 1 & Rendah \\
\hline \multicolumn{2}{l}{ Total skor } & 10 & Rendah \\
\hline
\end{tabular}

Sumber: Data Primer diolah Tahun 2019

\section{Partisipasi pada Tahap Perencanaan}

Hasil penelitian menunjukkan bahwa partisipasi responden dalam tahapan perencanaan pada kegiatan usahatani tanaman pangan adalah rendah, dimana jumlah skornya 4. Untuk lebih jelasnya dapat dilihat pada tabel 7 berikut.

Tabel 7. Partisipasi pada Tahapan Perencanaan

\begin{tabular}{llll}
\hline No & Variabel & Modus & Kategori \\
\hline 1 & Keterlibatan dalam Merumuskan Materi & 1 & Rendah \\
2 & Keterlibatan dalam Menentukan Metode dan Media & 1 & Rendah \\
3 & Keterlibatan dalam Menentukan Waktu dan Tempat & 2 & Rendah \\
\hline Total skor & 4 & Rendah \\
\hline
\end{tabular}

Sumber: Data Primer diolah Tahun 2019

Data pada tabel 7, menunjukkan bahwa pada kegiatan merumuskan materi termasuk dalam kategori rendah. Materi penyuluhan pertanian yang akan disampaikan penyuluh kepada petani maupun perempuan tani diharapkan dapat memberikan dampak yang positif kepada peningkatan kesejahteran masyarakat. Oleh karena ini didalam memilih materi penyuluhan haruslah benar-benar sesuai dengan kebutuhan sasaran dalam hal ini petani yang melakukan kegiatan usahatani sehingga dalam merumuskan materi petani maupun perempuan tani tidak dilibatkan.

Kegiatan menentukan metode dan media termasuk dalam kategori rendah. Dalam kegiatan penentuan materi dan media hanya penyuluh yang terlibat karena metode penyuluhan merupakan cara penyampaian materi penyuluhan kepada petani agar mereka mau dan mampu menolong dan mengorganisasikan dirinya dalam mengakses informasi pasar. Berdasarkan hasil penelitian metode yang disampaikan penyuluh pada saat kegiatan penyuluhan berlangsung yaitu ceramah atau diskusi dan demonstrasi dan media yang digunakan adalah media lisan.

Penyuluhan di Kecamatan Sakra Barat dilaksanakan setiap minggunya empat kali secara rutin. Masingmasing kelompok tani telah memiliki jadwal penyuluhan sendiri-sendiri. Namun penetapan waktu tersebut terkadang bisa berubah sesuai dengan kesepakatan bersama dari penyuluh dan sasaran. Hal ini bisa terjadi dikarenakan ada kesibukan antara penyuluh maupun dari petani. Tempat pelaksanaan penyuluhan di Kecamatan Sakra Barat dilakukan di dalam ruangan dan terkadang dilaksanakan di luar ruang atau di lapang. Data pada tabel 7, menunjukkan bahwa partisipasi responden pada kegiatan menentukan waktu dan tempat termasuk dalam kategori rendah. Rendahnya partisipasi responden pada tahapan ini disebabkan karena responden kurang dilibatkan oleh ketua kelompok tani.

\section{Partisipasi pada Tahapan Pelaksanaan}

Pelaksanaan dalam kegiatan penyuluhan tanaman pangan yang dimaksud dalam penelitian ini adalah keterlibatan dan kehadiran dalam setiap kegiatan pada penyuluhan tanaman pangan di Kecamatan Sakra Barat yang dimulai dari keterlibatan dalam mempersiapkan tempat, kehadiran perempuan pada kegiatan penyuluhan pertanian dan keterlibatan dalam diskusi kelompok.

Hasil penelitian menunjukkan bahwa partisipasi responden dalam tahapan pelaksanaan pada kegiatan penyuluhan tanaman pangan adalah sedang, dimana jumlah skornya 6 . Untuk lebih jelasnya dapat dilihat pada tabel 8 berikut.

Tabel 8. Partisipasi pada Tahapan Pelaksanaan

\begin{tabular}{llll}
\hline No & Variabel & Modus & Kategori \\
\hline 1 & Keterlibatan dalam Mempersiapakan Tempat & 2 & Sedang \\
2 & Kehadiran Perempuan Tani pada Kegiatan Penyuluhan Pertanian & 2 & Sedang \\
3 & Keterlibatan dalam Diskusi Kelompok & 2 & Sedang \\
\hline Total skor & 6 & Sedang \\
\hline
\end{tabular}

Sumber: Data Primer diolah Tahun 2019 
Data pada tabel 8, menunjukkan bahwa pada kehadiran responden pada kegiatan penyuluhan tanaman pangan termasuk dalam kategori sedang. Dalam hal ini dapat dilihat dari jumlah responden yang ikut dalam kegiatan penyuluhan tanaman pangan tersebut yaitu sebesar 26 orang, karena sebagian besar responden sudah mengerti pentingnya mengikuti kegiatan penyuluhan tanaman pangan selain itu banyak perempuan tani yang ditinggal suami menjadi TKI sehingga kewajiaban suami yang menjadi anggota kelompok untuk mengikuti kegiatan penyuluhan digantikan oleh responden tersebut, bahkan ada yang menggantikan suaminya menjadi ketua kelompok.

Partisipasi responden pada keterlibatan dalam diskusi kelompok pada kegiatan penyuluhan tanaman pangan termasuk dalam kategori sedang. Kategori sedang ini menunjukkan bahwa sebagian besar responden melakukan diskusi secara berkelompok. Anggota kelompok dikatakan sering mengikuti kegiatan ini umumnya sering berkumpul dan berdiskusi pada setiap pertemuan berlangsung mengenai segala hal yang terkait dengan usahataninya, baik setalah mengikuti pertemuan maupun diluar pertemuan kelompok. Diskusi ini sering dilakukan di berbagai tempat, sepeti di pematang sawah, lesehan sekitar sawah, rumah ketua maupun anggota kelompok tani.

\section{Partisipasi pada Tahapan Evaluasi}

Hasil penelitian menunjukkan bahwa partisipasi responden dalam tahapan evaluasi adalah rendah, dimana jumlah skornya adalah 1. Pada tahapan evaluasi secara umum partisipasi responden adalah rendah. Hal ini ditunjukkan dengan rendahnya keterlibatan responden dalam kegiatan pelaksanaan pada penyuluhan tanaman pangan.

Keterlibatan dalam kegiatan pelaksanaan evaluasi pada kegiatan penyuluhan tanaman pangan termasuk dalam kategori rendah. Rendahnya partisipasi responden disebabkan karena dalam kegiatan evaluasi memiliki beberapa tahapan yaitu Evaluasi proses adalah evaluasi yang dilakukan untuk mengevaluasi seberapa jauh proses kegiatan yang telah dilakukan dan Evaluasi hasil adalah evaluasi yang dilakukan untuk mengevaluasi tentang seberapa jauh tujuan-tujuan yang direncanakan telah dapat dicapai. Dari setiap tahapan yang dijelaskan diatas dapat disimpulkan bahwa petani maupun responden tidak terlibat dalam setiap tahapan evaluasi mulai dari proses evaluasi sampai dengan hasil evaluasi, yang terlibat hanyalah penyuluh.

\section{Kendala-Kendala dalam Kegiatan Penyuluhan}

Meskipun responden memiliki partisipasi yang tinggi dalam kegiatan tanaman pangan hal ini tidak berarti bahwa partisipasi perempuan dalam kegiatan penyuluhan tanaman pangan, khususnya yang dilakukan oleh penyuluh juga tinggi.

kendala yang dihadapi responden yang telah mengikuti kegiatan penyuluhan yaitu jarak yang terlalu jauh dengan rumah responden, waktu yang kurang tepat karena biasanya penyuluhan berlangsung pada pagi hari sekitar jam 9 sedangkan perempuan tani sedang sibuk memasak dan membersihkan rumah, tempat yang kurang nyaman karena berdekatan dengan kandang hewan. Selain itu kendala yang dihadapi responden yaitu faktor umur karena penglihatan mulai memburuk serta pendengaran yang mulai tergannggu sehingga responden membutuhkan alat pengeras suara. Kemudian ada beberapa responden yang sulit memahami materi yang disampaikan karena penyuluh yang menyampaikan materi biasanya menggunakan nama lain dari sebuah alat atau nama latin dari organisme pengganggu tanaman yang sulit dimengerti oleh responden misalnya mesin combine harvester atau mesin pemanen padi dan belalang atau, sedangkan responden yang memiliki pendidikan yang rendah sulit untuk memahami.

Kendala yang dihadapi responden yang tidak mengikuti kegiatan penyuluhan yaitu tidak pernah diundang dan bukan anggota kelompok tani karena yang menjadi anggota dalam kelompok tani tersebut adalah suami. Tetapi banyak perempuan tani yang ditinggal suami menjadi TKI sehingga kewajiban suami yang menjadi anggota kelompok untuk mengikuti kegiatan penyuluhan digantikan oleh responden tersebut. Perempuan tani yang tidak menhadiri penyuluhan tetap mendapatkan informasi dari suami yang telah mengikuti kegiatan penyuluhan tersebut, mengingat partisipasi perempuan tani dalam kegiatan usahatani tinggi dan membutuhkan informasi sehingga usahatani yang dihasilkan bisa lebih maksimal.

\section{KESIMPULAN DAN SARAN}

\section{Kesimpulan}

Berdasarkan hasil penelitian dan pembahasan, maka kesimpulan yang dapat ditarik dari penelitian ini adalah:

1. Tingkat partisipasi responden dalam kegiatan usahatani tanaman pangan di Kecamatan Sakra Barat termasuk dalam kategori tinggi dengan jumlah perempuan tani sebanyak 32 orang (71\%) dan sebanyak 13 orang $(29 \%)$ memiliki tingkat partisipasi yang sedang. 
2. Tingkat partisipasi responden dalam penyuluhan tanaman pangan di Kecamatan Sakra Barat termasuk dalam kategori rendah dengan jumlah perempuan tani sebanyak 41 orang (91\%) dan sebanyak 4 orang (9\%) memiliki tingkat partisipasi yang sedang.

3. Kendala-kendala yang mempengaruhi rendahnya partisipasi responden dalam kegiatan penyuluhan yaitu jarak yang jauh, waktu yang kurang tepat dan tempat yang kurang nyaman, umur dan penglihatan yang buruk, kurangnya penyuluh perempuan, tidak bisa membaca dan menulis, pendengaran yang terganggu, kurangnya pengeras suara, kesulitan dalam memahami materi yang disampaikan, tidak diundang dan bukan anggota kelompok.

Saran

Berdasarkan hasil penelitian, pembahasan dan kesimpulan, peneliti mengajukan beberapa saran yaitu:

1. Untuk pengurus kelompok tani harus bisa dan mampu mengkoordinir setiap anggota kelompoknya sehingga apabila diadakan kegiatan penyuluhan semua anggota kelompok tani dapat hadir. Hal tersebut bertujuan untuk meningkatkan partisipasi anggota kelompok dalam setiap kegiatan kelompok.

2. Untuk penyuluh kelompok tani, harus menjadwal kegiatan penyuluhan agar sesuai dengan waktu anggota kelompok tani yang kosong dan menjadikan perempuan tani anggota kelompok tani mengingat partisipasi perempuan tani dalam kegiatan usahatani tinggi. Selain itu penyuluh seharusnya menggunakan bahasa yang mudah dimengerti.

3. Untuk Pemerintah, perlu adanya perhatian yang tinggi akan pentingnnya penyuluhan bagi perempuan tani mengingat partisipasi perempuan tani pada kegiatan usahatani tergolong tinggi, seperti perbanyak penyuluh perempuan, agar responden tersebut mampu berfikir lebih maju dan inovatif.

\section{DAFTAR PUSTAKA}

Hayati. 2015. Partisipasi Perempuan Tani Dalam Mencapai Ketahanan Pangan Rumah Tangga (Kasus Di Kabupaten Lombok Timur Provinsi Nusa Tenggara Barat). Disertasi Sekolah Pascasarjana Institut Pertanian Bogor. IPB. Bogor

Kementerian pertanian. 2015. Badan penelitian dan pengembangan pangan BPKP. Rencana strategis badan pengawasan keuangan dan pembangunan perwakilan provinsi nusa tenggara barat.

Listiani. 2012. Gender dan Komunitas Perempuan Pedesaan. Medan (ID): Bitra Indonesia.

Mardikanto, Totok. 2009. Sistem Penyuluhan Pertanian.[skripsi unpublished]. Fakultas pertanian, Universitas Sebelas Maret. Solo. Indonesia.

Mulyaningsih A, Hubeis AVS, Sadono D, Susanto D. 2018. Partisipasi Petani pada Usahatani Padi, Jagung, dan Kedelai Perspektif Gender. J. Penyuluhan Institut Pertanian Bogor (IPB) Vol 14(1).

Nazir. 2005. Metode penelitian. Bhalia Indonesia. Jakarta. 